\title{
Archives in Libraries: What Librarians and Archivists Need to Know to Work Together
}

\author{
Bastian, Jeannette A., Megan Sniffin-Marinoff, and Donna Webber. Archives in Libraries: \\ What Librarians and Archivists Need to Know to Work Together. Chicago: Society of \\ American Archivists, 2015. 137 pp. \$69.95. ISBN: 9781931666879.
}

The volume Archives in Libraries: What Librarians and Archivists Need to Know to Work Together explains what archivists do and why they do it, particularly for librarians who work within the context of an academic library. The authors, all archivists, assert that librarians often do not understand the archival profession, nor do they fully appreciate the extent of the work archivists perform in their vocation. The authors also note that some archivists do not know how to advocate for their work, nor are they able to explain their essential needs in the workplace to library directors. Ultimately, the book considers the notion that "both the library director and the library staff could benefit from a deeper understanding of what an archive is or can be, what it does, and how it fits within the overall mission of the institution" (2).

The purpose of the book is to provide "an overview of the basic archival concepts, policies, and best practices for librarians and library directors, while also suggesting the ways in which archivists working in libraries can describe their work and effectively advocate for archival needs" (5). The authors surmise that by explaining what archivists do, and how they do it, the book will "narrow the divide and build shared understandings among archivists, librarians, and library directors while helping archivists working within libraries to better negotiate their relationships with the institution and with their library colleagues" (5). Thus, library directors will better appreciate all that goes into creating and managing archives within the context of a library. The book is also an attempt "to help archivists in library settings imagine ways to advocate fruitfully for their programs" (6). Through an overview of various standards, best practices, and shared missions, the authors are hopeful that each profession and its practitioners will "understand their similarities and differences to create a beneficial and reciprocal working relationship" (6).

The intended readership of the volume includes both librarians and archivists, but the book functions particularly as a primer for library directors, to help them better understand the archival profession and to have an awareness of the professional tasks archivists perform in an academic setting. The authors conducted a series of interviews, which included fifteen archivists and, surprisingly, only eight library directors. Interviews ranged from 40 to 60 minutes, and separate sets of questions were prepared for participating archivists and for library directors. The interviews were made into transcripts, which were used as primary source material for the volume. The authors also drew on several earlier studies from each profession describing the intersections, tensions, and possibilities between archivists and librarians.

The book is divided into three sections and includes several vignettes which attempt to help readers better understand the work of archivists. According to the authors, the vignettes "are loosely based on real-life experiences of the authors and interviewees" and "supplement the text by providing targeted examples addressing current topics" (7). The volume includes an appendix, several charts, a bibliography and an index. Part I, titled "Setting the Stage," considers the professional identities and shared missions and values of each profession; it explores the evolving definitions of the scope of work between the two vocations while also examining the educational trajectories of archivists and librarians — including a brief overview of their main respective professional organizations, the Society of American Archivists and the American Library Association. Part II, titled "Considering the Work," explains archival workflows, including acquiring collections, records management, appraisals, processing, preservation, access, reference, outreach, and donor relations. The final chapter of the section asks several practical and logistical questions, including: Why and how does a library establish archives? What are the issues and concerns regarding the planning and management of archives? Which resources and accommodations are needed to effectively embed archives within a library setting? Part III, titled "Considering the Issues," reviews the ethical practices of the two professions, ranging from making resources available to protecting the privacy of patrons. This section explores issues common to both professions, such as information literacy, digital access, and digital preservation. Finally, the authors envision possible efforts toward cooperation and collaboration. 
The volume confirms that both archivists and librarians have an intentional sense of vocational mission that includes service to users, their institutions, and their communities. For archivists concerned with librarians functioning in an archival role, the book is a helpful reminder of the distinctive nature of the two professions. Historically, both libraries and archives have focused on access to information and the keeping of the official record. Libraries have and continue to focus primarily on providing patrons with access to a wide array of information, while the purpose of an archive is to intentionally protect and preserve the historical records of institutions and communities. For librarians hoping to acquire a snapshot of the duties of the archival profession, or to envision working together with newly hired archivists, the volume provides helpful directives to better understand archivists and their archives. The authors note, "Identifying similarities and differences is useful in understanding gaps and areas of concern, but simply explaining archives to librarians might go a long way toward establishing productive work environments" (7).

While understanding what archivists do is essential for library directors intending to hire an archivist, the volume often seems to be one-directional in focus. The subtitle of the book, What Librarians and Archivists Need to Know to Work Together, implies some form of mutual appreciation and understanding between the two professions. Yet, this shared perspective somehow gets lost in the narrative, as the voices of librarianship and the librarians who have and will work in contexts alongside archivists remain largely silent outside the small sample pool interviewed for the study.

Unfortunately, no librarians appear to have been involved in the writing process or in the editorial work of the book. Collaborating with librarians on the genesis and development of the manuscript, at least as conversational partners or preliminary readers, would have helped nuance the overgeneralizations of librarians, such as when the authors mention the apparent "gaps in understanding that affected the ability of archives to succeed" (v). The small sample pool of librarians does not provide the necessary fuller perspective on how many librarians view the archival profession. The authors are not clear as to whether those eight directors were professional librarians, or if they were credentialed in other professions while functioning as librarians.

Finally, there is little explanation regarding the work and duties of special collections librarians. These specialized librarians can function, and in smaller library contexts often do function, as helpful bridges between the professions. The perspectives of these librarians seem essential for this volume and would have helped further demonstrate that special collections librarians often do have a basic knowledge of the archival profession and do fully appreciate the vocational intersections between archivists and librarians. While many special collections librarians are not credentialed archivists, they are often appointed to function as archivists for smaller educational contexts such as a theological or seminary library.

Overall, the authors provide readers with an overarching description of the work of archivists. While the inclusion of more librarians in the project would have provided a fuller picture of how librarians think about the archival profession and the vocational responsibilities of archivists, the volume is a worthwhile addition for the shelves of library directors, special collections librarians, and archivists who report to librarians. Ultimately, the book demonstrates the need for the two professions to foster relationships amongst each vocational community and to provide "one more step in the effort to achieve harmony and empathy" between the professions (3-4).

Christopher J. Anderson Special Collections Librarian Yale Divinity Library New Haven, Connecticut 